\title{
CORRESPONDENCE
}

\section{I.U.G.S. Precambrian/Cambrian Boundary Working Group in Siberia, 1973}

(Plates 1-4)

SIR,-We offer to your readers an account of the International Precambrian/Cambrian Boundary Working Group's participation in a Symposium in Siberia during June and July of 1973.

\section{Introduction}

A field excursion sponsored by the Academy of Sciences, U.S.S.R., was held from 28 June to 13 July 1973 to consider possible stratotypes for the Precambrian/Cambrian Boundary along the middle courses of the Aldan and Lena Rivers in Yakutia, eastern Siberia. Some attention was also given to the Lower/Middle Cambrian Boundary. Outcrops and fossils of the Yudomian, Tommotian, Atdabanian and Lenian (sensu lato) Stages were examined in river cliffs. The excursion was organized by the Geological Institute of the Academy of Sciences of the U.S.S.R. (GIN); the Institute of Geology and Geophysics of the Siberian Section of the Academy of Sciences of the U.S.S.R. (IGIG); the Yakutsk Affiliate of the Siberian Section of the Academy of Science of the U.S.S.R. (IGYaFSOAN); and the Siberian Research Institute of Geology, Geophysics and Mineral Deposits (SNIIGGIMS).

There were 28 foreign geologists (from Australia, B.R.D., Britain, Canada, Denmark, D.D.R., France, Iran, Poland, Sweden, U.S.A.) who were accompanied and guided by up to 60 geologists of the U.S.S.R. As part of this company of nearly 90 were 8 members of the Precambrian/Cambrian Boundary Working Group constituted by the Commission on Stratigraphy of the International Union of Geological Sciences and including members of the Subcommissions on both Precambrian and Cambrian Stratigraphy. Members of the Interdepartmental Stratigraphic Committee of the U.S.S.R. were also present.

\section{The excursions and discussions}

\section{2.a. The River Aldan}

The foreign guests assembled in Moscow on 27 June and flew to Yakutsk, where large helicopters took them and their Russian hosts to a tented camp on the banks of the Aldan (Fig. 1). Three days were spent examining outcrops of the Yudoma, Pestrotsvet and Tumuldur formations in river bluff sections along the Aldan river using transport by large, shallow-draught river boat. The succession near the base of the richly fossiliferous Pestrotsvet Formation received special attention as a candidate for the stratotype of the Precambrian/Cambrian Boundary.

The first day (1 July) at Dvortsy was spent examing the Yudoma, Pestrotsvet and Tumuldur formations; the base of the Pestrotsvet, which contains archaeocyathids, gastropods, hyolithelminths, etc., had been dated at about $575 \mathrm{~m} . y$. (K/Ar on glauconite); its uneven, slightly disconformable contact on the underlying Yudoma, which is poorly fossiliferous but contains stromatolites and microphytolites, suggests a time gap of unknown length. Blocks, probably Yudoma, with abundant trace fossils, were inspected in the float. Ulakhan-Sulugur (Plate 1, figs. 2-3) aroused great interest on 2 and 3 July as being probably the best exposure on the Aldan for the putative Precambrian/Cambrian Boundary at (or slightly below) the base of the Pestrotsvet Formation (Bed 12), which rests on an uneven, pocketed surface of the Yudoma, suggesting a disconformity. Within

Geol. Mag. 111 (3), 1974, pp. 237-252. Printed in Great Britain. 

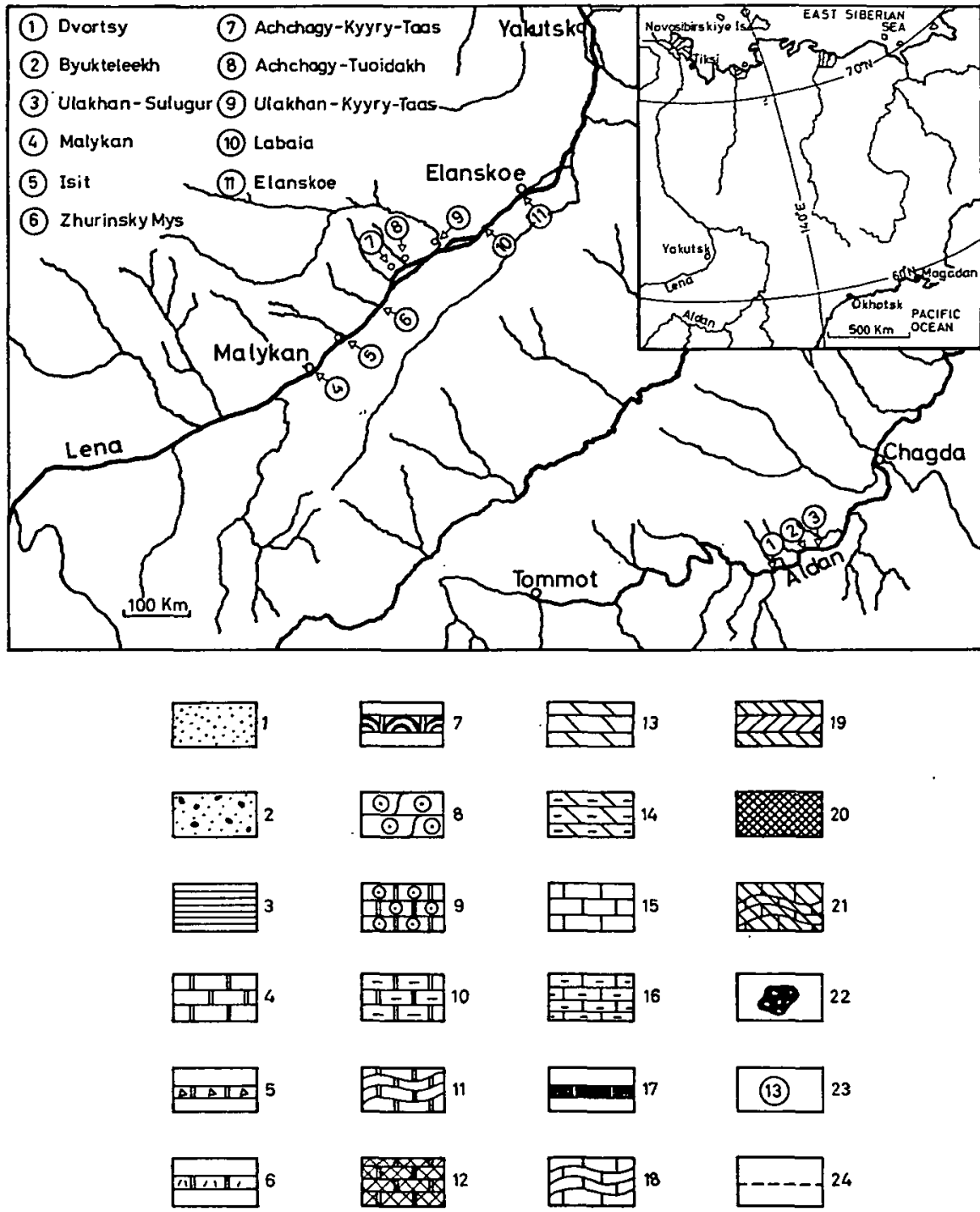

$O_{25} \quad P_{26} \quad J^{27} \quad A^{28} \Theta_{29} \quad F_{30} \quad x^{31} \quad 0_{32} \uparrow^{33} \oplus_{34} \quad \Delta_{35} \bigcirc_{36}$ ${ }_{37}^{37}-38 \quad-.-.-39$

Fig. 1. For legend see facing page. 
the Yudoma, $1.5 \mathrm{~m}$ below the base of the Pestrotsvet Formation is a thin stratum (Bed 8) of glauconite-carbonate sandstones which is impersistent laterally, rests with slight washout on brecciated dolomites and contains fragments of archaeocyathids, hyolithids, hyolithelminths and other fossils. Investigations and discussion developed the opinion by many that Bed 8 accumulated at the time of deposition of Bed 12 by downward movement of glauconitic sediment and fossil fragments along solution-enlarged fractures and bedding joints in already lithified dolomite of the Yudoma Formation. Connecting fissure-fillings joining up the two beds were convincingly pointed out. Others believed, however, that the movement was in the reverse direction, from Bed 8 upwards to Bed 12. Beds 9,10 and 11 had previously been found by Soviet palaeontologists to contain fragmentary shelly fossils including Chancelloria.

An evening discussion in camp, chaired by Professor Keller, commenced with statements by workers in the area: Zhuravleva, Khomentovsky, Rozanov, Missarzhevsky and Korshunov (see Appendix for list of participants). Points touched on included (a) the suggested principle of basing the Cambrian at the appearance of shelly fossils and $(b)$ the development elsewhere of Nemakit-Daldyn strata. Savitsky, supported by Daily, Palmer, Aitken and Choubert, postulated the need for a boundary stratotype in a continuous monofacial marine section, claiming that the Aldan sections were not monofacial and that the abrupt appearance of fauna there may only be due to migration. Harland agreed but advocated taking advantage of the visits to these fossiliferous well-studied sections to consider a higher position within the Pestrotsvet where there is a continuous monofacial marine sequence with good correlation elsewhere by means of the rich fauna; he pointed out that the placing of the Precambrian/Cambrian Boundary will in any case be a man-made decision. Rodgers considered that everyone would include the sunnaginicus zone (found at the base of the Pestrotsvet Formation) in the Cambrian but stressed that there was no general agreement on the age of the Yudoma. He made a plea for the use of question marks to stress uncertainty, e.g. ?Cambrian, ?Precambrian or ?Cambrian/?Precambrian, until much more information is available.

\section{2.b. River Lena}

On 4 July the group was flown back to Yakutsk and the size of the party was increased by new Soviet arrivals. About 90 geologists spent the next nine days aboard the wellequipped and spacious river ship 'Rossia' examining river-cliff outcrops of Lower and early Middle Cambrian age between Malykan and Elanka (Fig. 1). The section at Isit included sedimentary rocks exposed at river level of possible latest Precambrian age.

With ship moored to the shore, as became customary, and with gangplank access to the exposures nearby, fossiliferous strata in the upper part of the Tommotian and Atdabanian stages were examined on 6 July at Malykan. Isit, visited on the following day, was

Figure 1. Map of part of Yakutia showing the localities 1-11 visited on the Aldan and Lena Rivers, with inset map of east Siberia relating the area to the Pacific Ocean (Sea of Okhotsk) and the Arctic Ocean (East Siberian Sea).

The numbers of the key to the symbols and ornament used in Figs. 2, 4 and 7 refer to the following: 1 , Sandstone; 2 , conglomerate; 3 , thin-bedded, platy, clay-carbonate rocks; 4 , dolomites; 5 , brecciose dolomites; 6 , dolomitic authigenic breccia; 7 , stromatolitic dolomites; 8 , cross-stratified oncolitic dolomites; 9 , oncolitic dolomites; 10 , clayey dolomites; 11 , wavy-bedded dolomites; 12 , patchy dolomites; 13 , dolomitized limestones; 14, clayey dolomitized limestones; 15 , limestones; 16 , clayey limestones; 17 , algal limestones (biostromes); 18, wavy-bedded limestones; 19, clay-rich, red-coloured limestones; 20 , limestone with clay lenses; 21 , wavy bedded limestone, bright red in colour; 22 , archaeocyathid bioherms; 23 , unit number; 24 , correlation lines; $25-36$, occurrences of fossils; 25 , archaeocyathids; 26 , hyolithids; 27 , hyolithelminthids; 28 , tommotiids; 29 , brachiopods; 30 , algae; 31 , chancelloriids and sponges; 32 , gastropods; 33 , trilobites; 34 , mobergellids; 35 , other skeletal fossils; 36 microphytolites; 37 , lower boundary of the Cambrian; 38 , boundaries between stages; 39 , boundaries between zones and subzones. 


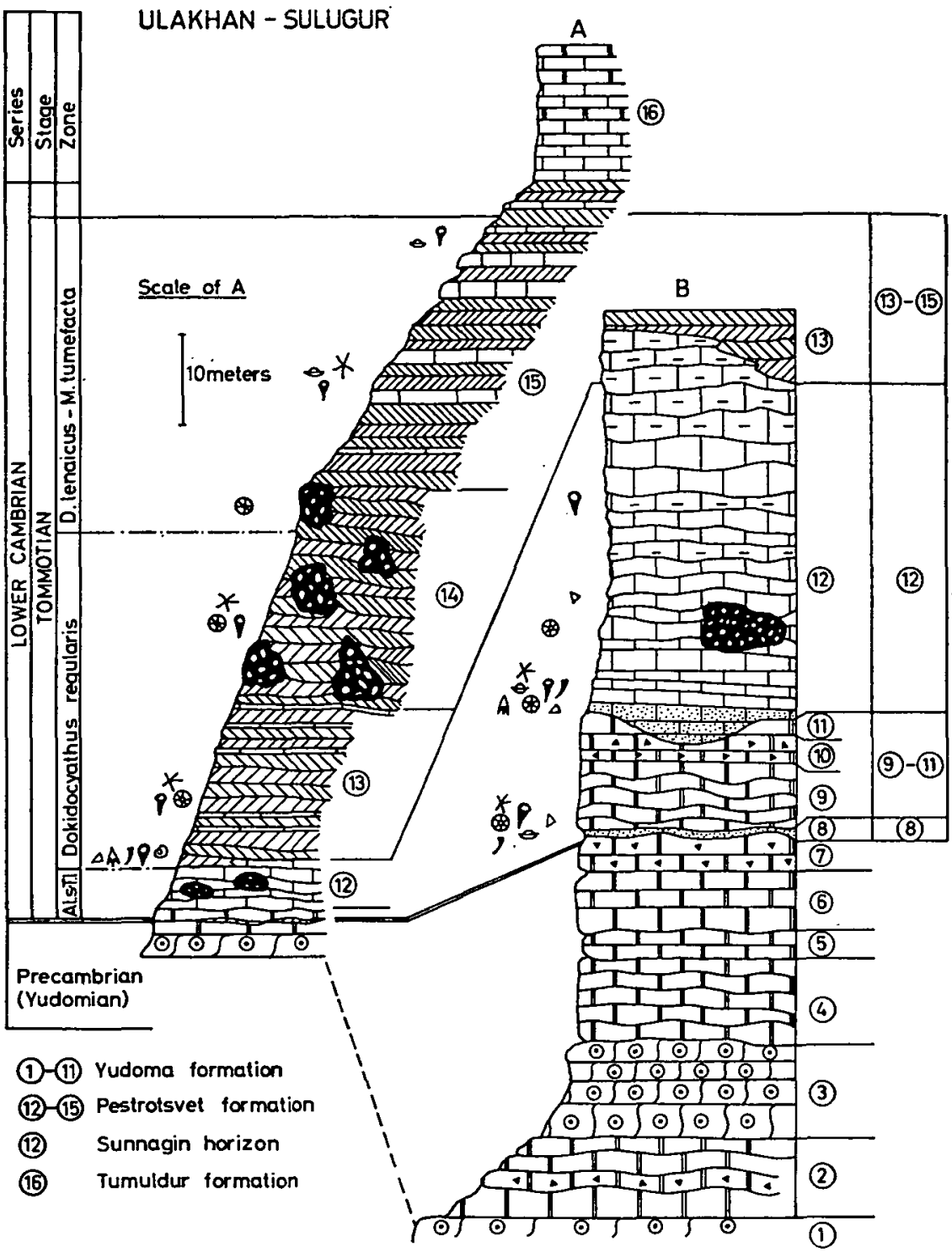

Figure 2. The composite vertical section at Ulakhan-Sulugur with representation of faunas (see Fig. 1 for explanation).

particularly interesting as a possible type-locality for the Tommotian Stage (Plate 2, figs. 4-6). Here Atdabanian Stage deposits yield the 'first' trilobites. A shelly fossil, probably a hyolithid, was located by Daily in the oldest Unit (1) in rocks lithologically similar to the Yudoma Formation. On 8 July Zhurinsky Mys (Plate 3, fig. 7) showed rocks and fossils of the Tommotian and Atdabanian stages including archaeocyathids 


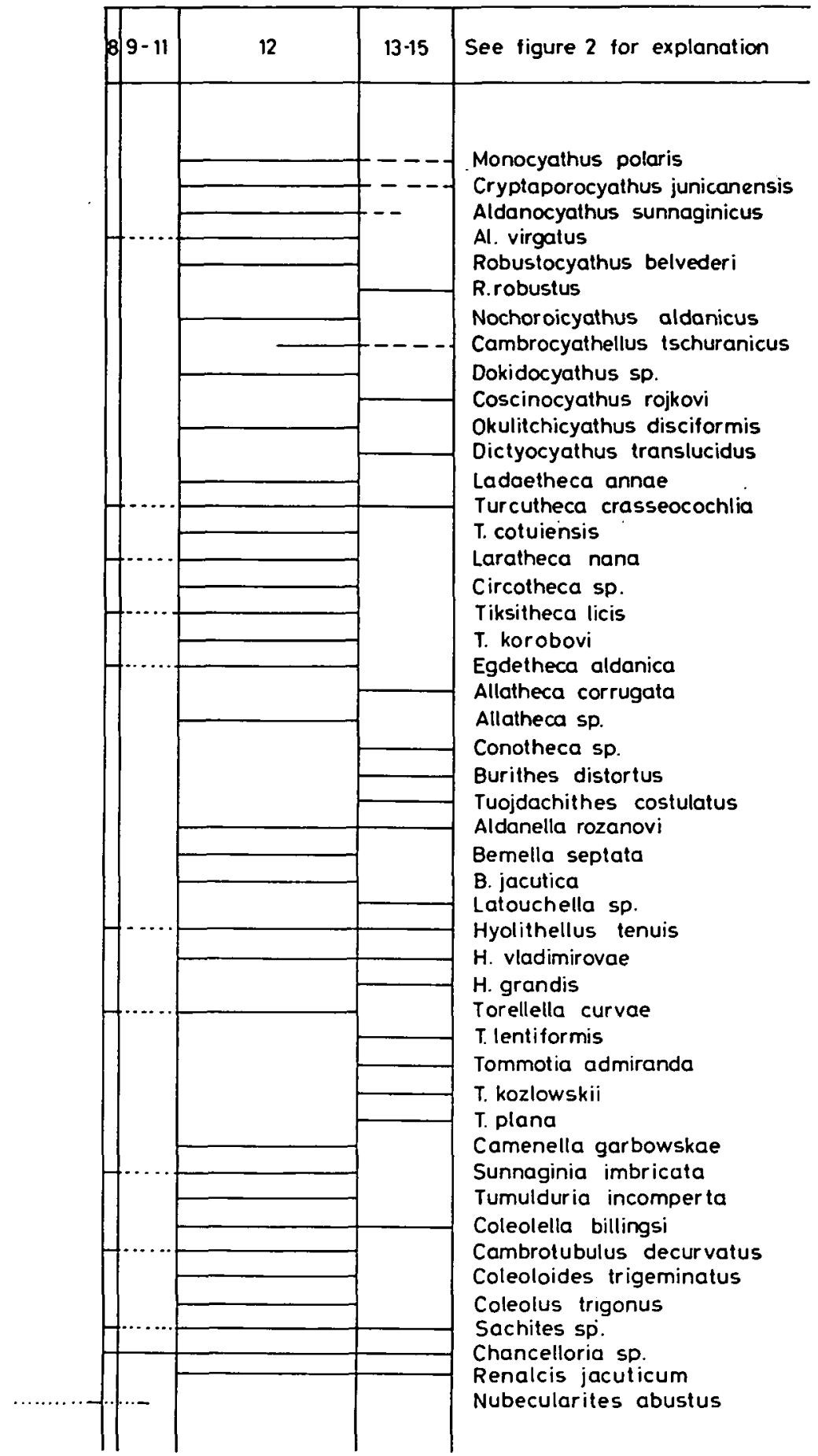

Figure 3. The stratigraphical distribution of the fauna in the sections at Ulakhan-Sulugur (see Fig. 2 where the numbers 8-15 are related to the succession). 


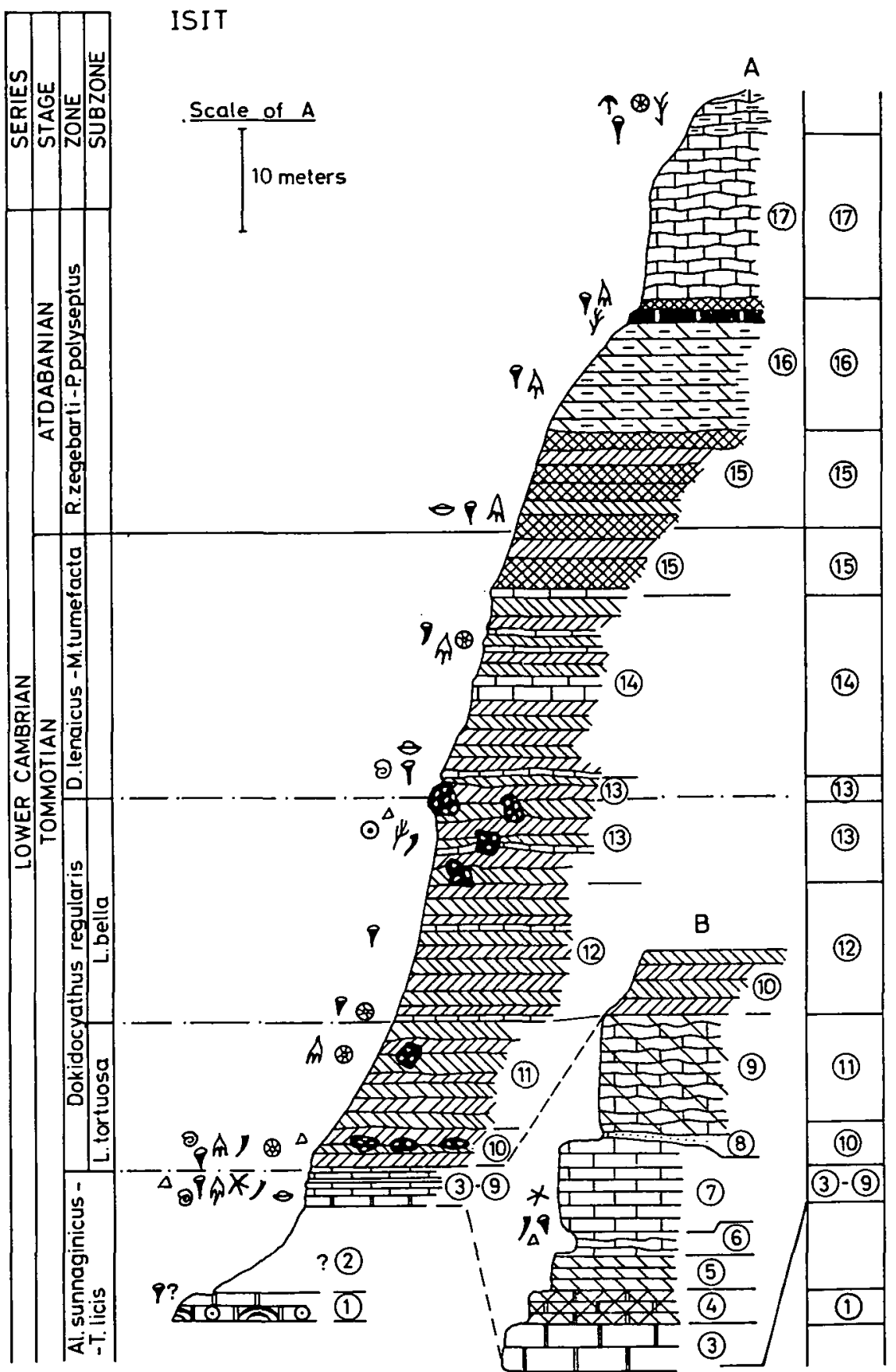

Figure 4. The composite vertical section at Isit with representation of faunas (see Fig. 1 for explanation). 


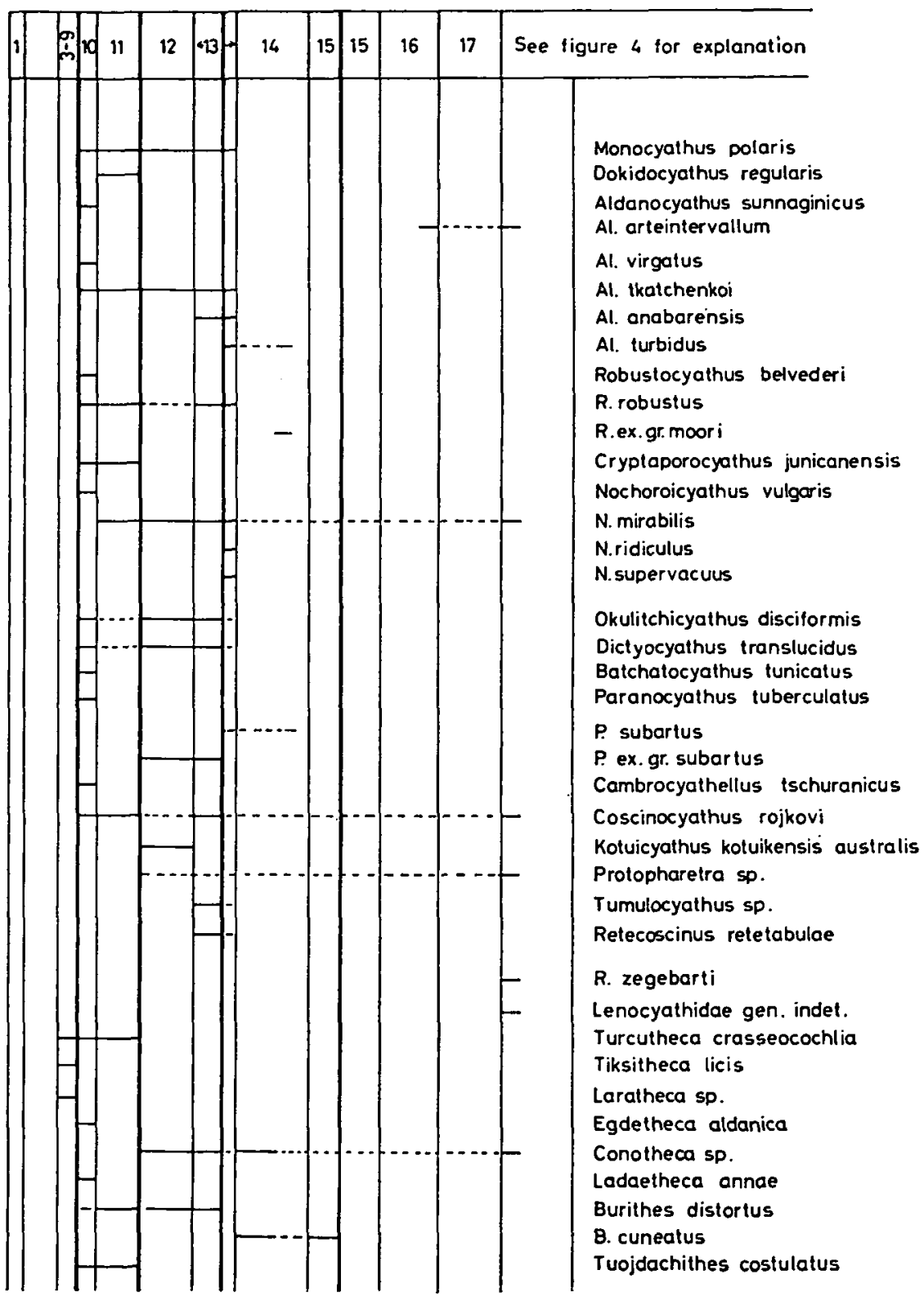

Figure 5. The stratigraphical distribution of the fauna in the sections at Isit (see Fig. 4, where the numbers 1-17 are related to the succession). 


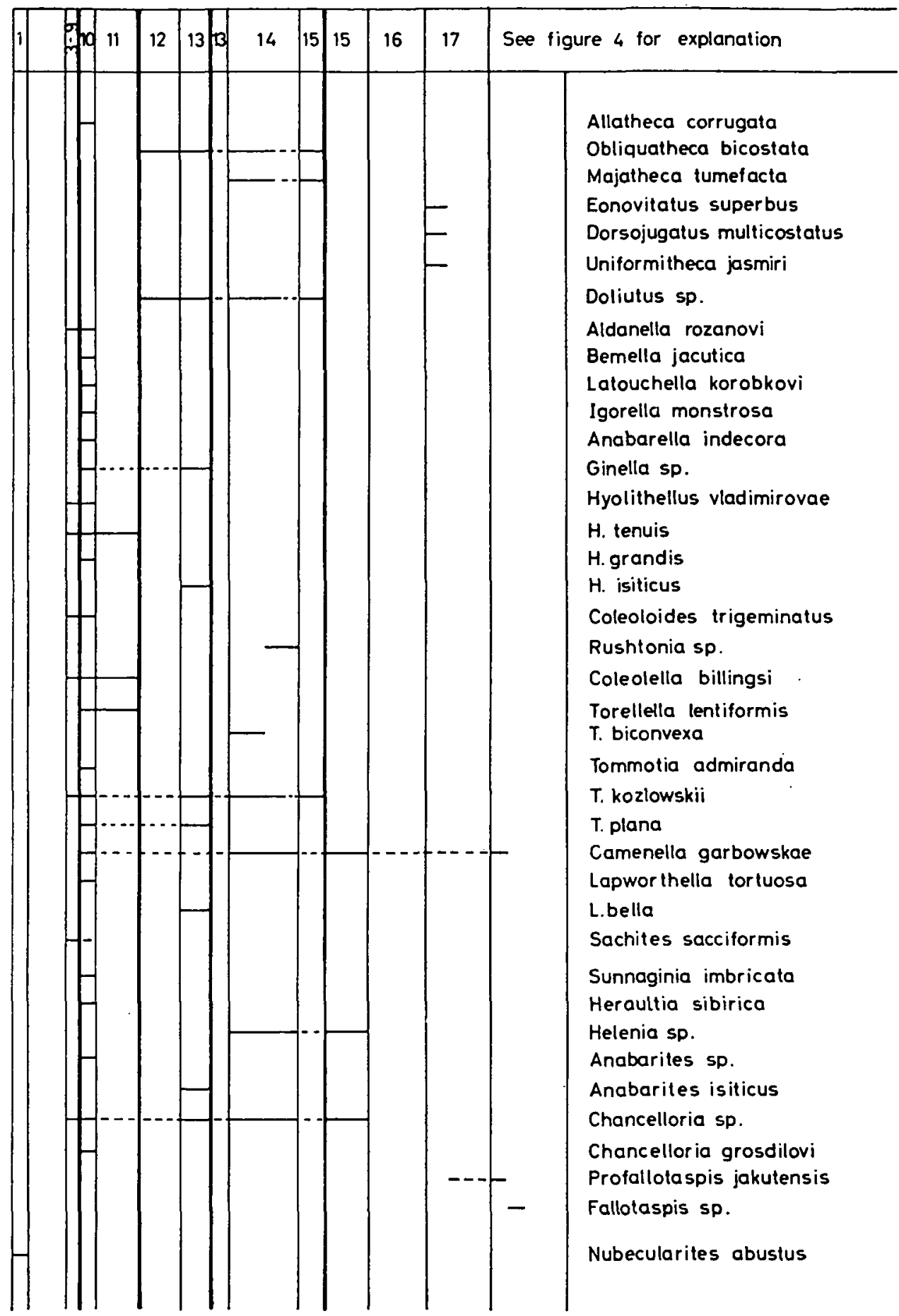

Figure 6. The stratigraphical distribution of the fauna in the sections at Isit, continued

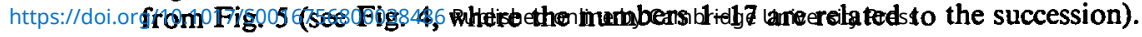




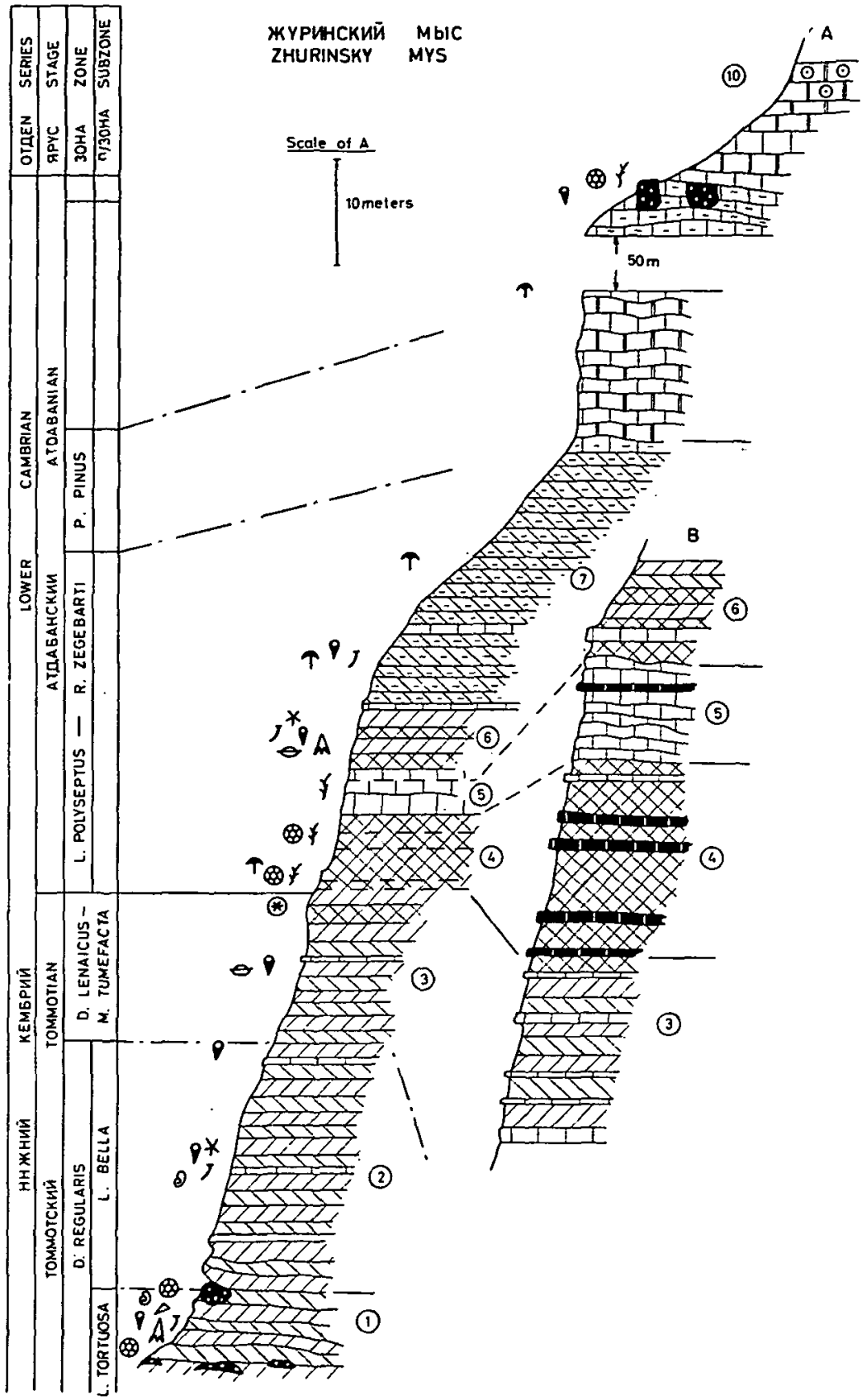

Figure 7. The composite vertical section at Zhurinsky Mys with representation of faunas (see Fig. 1 for explanation). 
and trilobites, and next day Achchagy-Kyyry-Taas exemplified the eastern, more calcareous, facies of the Atdabanian Stage, with trilobites at many levels in association with archaeocyathids, hyolithids and other fossils. Achchagy-Tuoidakh, Ulakhan-KyyryTaas, Labaia (Plate 4) and Elanskoe were visited from 9 to 12 July to demonstrate later Lower and early Middle Cambrian successions.

\section{2.c. Discussions}

Formal and informal discussions on almost all aspects of Lower Cambrian stratigraphy and faunas involved foreign and Soviet geologists in lengthy sessions in the late afternoons and evenings of most days. Topics included were:

1. Zonation in the early Cambrian and late Precambrian.

2. Evidence for the correlation of Siberian strata with those in other regions of the world.

3. The problem of the age and correlation of the Nemakit-Daldyn strata found in Siberian regions other than the Aldan and Lena.

4. The principles of defining the Precambiran/Cambrian Boundary.

5. Facies control and possible diagenetic phosphatization of several problematical fossils considered typical for the Tommotian Stage.

6. Lower Cambrian Stages and in particular the definition and correlation of the Tommotian Stage.

7. The possible use of acritarchs in relation to the drawing of the Precambrian/ Cambrian Boundary.

Discussions involving the whole conference were held on four occasions on the Lena River and minutes were kept; the chair was taken in turn by Aitken, Cowie, Menner, Palmer, Rodgers and Savitsky.

On 5 July Rozanov agreed to an earlier comment by Savitsky on procedure for establishing a type-section but proposed a compromise in adopting the best available stratotype point in the absence of an ideal. Matthews outlined microfossil and other evidence from England, Sweden and Australia for correlations with Siberia. Menner maintained that there is no single principle for drawing the boundary and as research continues so the boundary may need relocation. In his opinion the Precambrian/Cambrian Boundary could be taken between the Yudomian and Tommotian, within the Tommotian or at the base of the Atdabanian. Savitsky gave a regional outline of the facies of the Cambrian in the Siberian platform. Khomentovsky thought that it was impossible to draw the Precambrian/Cambrian Boundary at the base of the sunnaginicus zone when there are significant fossils below this base. He suggested that the Yudoma River section was a suitable place for the boundary stratotype and that the Nemakit-Daldyn strata would prove more fossiliferous as they are studied further.

On 6 July a paper by Academician Sokolov (absent due to illness) was read in part by Khomentovsky and Cowie. Menner then spoke on late Precambrian and early Cambrian fossil zones, including the use of stromatolities, acritarchs and the Ediacara-type fauna. Keller spoke of the results of the All-Union conference held in Ufa (in the Urals) and the principles in defining the Precambrian/Cambrian Boundary. Daily spoke about the possibility of a lower position for the Precambrian/Cambrian Boundary at the base of the Russian Platform's Baltic Stage and below the Nemakit-Daldyn of the Siberian Platform. Sokolov's displayed chart showing Precambrian/Cambrian stratigraphy in Russia and Siberia revealed some uncertainties and evoked proposals for changes. Menner urged the use of biostratigraphical and palaeoenvironmental analysis and that below as well as above any Precambrian/Cambrian Boundary there must be comparable groups of fossils such as calcareous algae, stromatolites, acritarchs and others.

On 8 July discussions started with topics 4 and 5 mentioned above and Sdzuy, Rushton, Matthews and Kazmierczak discussed primary and secondary phosphatization, especially in relation to the Tommotian Stage, facies and discontinuities. Choubert next posed the question as to whether the earliest trilobites in Morocco were older than Profallotaspis, and if so were they Tommotian? The answers seemed inconclusive at the present stage of research. The boundaries of the Tommotian Stage were outlined by 
Repina. Burmann and Kiryanov agreed that present knowledge was inadequate to justify the use of acritarchs in drawing the Precambrian/Cambrian Boundary but Missarzhevsky supported using anabaritids for this purpose. Lazarenko outlined studies of acritarchs culled during the last ten years from continuous Precambrian/Cambrian sections in the U.S.S.R. Arctic.

On 12 July Lower Cambrian stages in Siberia were discussed with an introduction by Savitsky. Rozanov spoke on the evolution of faunal assemblages through the Lower Cambrian, Repina outlined the Botomian Stage and its trilobites and in conclusion Menner discussed the definition of the various Stages. This was followed by discussions on the Lower/Middle Cambrian Boundary with contributions by many including Bognibova, Chernysheva, Fletcher, Palmer and Suvorova. The three positions proposed at Elanka in the cliff sections were scrutinized. The need for a stratotype boundary point for the Lower/Middle Cambrian boundary was emphasized.

\section{Stratigraphic Questionnaire}

The more general stratigraphic principles involved in a selection of the most suitable internationally agreed level for the Precambrian/Cambrian Boundary, and the selection of regional stratotype sections elsewhere leading to the establishment of an International Stratotype Section and Point will be pursued at a planned meeting of the Working Group in Paris in June 1974. The following specific questions were put to all members of the Precambrian/Cambrian Working Group with a request for written responses and others also replied verbally or in writing. A short summary is difficult but the following points emerged in the answers received:

\section{3.a. Are palaeontological methods sufficient guidance in selecting a suitable Precambrian/ Cambrian Boundary?}

The answer was in general a clear 'Yes'. Remarks include 'the only possible solution', 'sufficient guidance in selecting a point for defining but not actually defining it'. 'Below the boundary should be a stratigraphic unit. . . with assemblages of skeletalized Metazoa different from those in the Cambrian. . . An attempt to determine the Lower Cambrian boundary as the level where skeletal forms appear is by no means successful.' 'The most favourable (additional) criterion is the Laplandian (Varegian) glaciation.' 'Les methodes géochronologiques' were mentioned. 'Palaeontological method is the only method in drawing the Cambrian/Precambrian boundary. However, lithological data must be taken into account.' 'The palaeontological methods alone are not a sufficient guide for the choice of the appropriate Precambrian/Cambrian Boundary.'

3.b. Do you consider that the first appearance of certain fossils that can be found in much later strata are sufficient for the establishment of the Precambrian/Cambrian Boundary or do you consider that account must be taken of the appearance of the first zonal assemblage with skeletalized shelly faunas?

There was more debate in the replies - answers included: 'No. First appearances are apt to be few, sporadic and liable to reassessment'; 'the lower boundary may be either at the first appearance of shelly fossils or within the sequence of shelly fossils. The question is still undecided.' 'No appearance of any fossils is sufficient for the establishing of the Precambrian/Cambrian Boundary. It must be established at a point in a rock sequence ideally rich in fossils for correlation elsewhere.' 'I prefer to see a zonal assemblage below the Precambrian/Cambrian Boundary as well as above it.' 'Best to draw the boundary at the first appearance of some assemblage of shelly fauna.' 'Drawing the boundary at first appearance of shelly fauna also persistent in much younger strata is fraught with serious error in the majority of cases.' 'Sans doute la toute première apparition des éléments faunistiques à squelette serait la plus satisfaisante.' 'The first zonal assemblage with skeletalized shelly fauna must not be taken into account for the lower boundary of the Cambrian, if we do not want to move the boundary down when new discovery is made.' 
3.c. Are there fossil animal zones (e.g. trace fossils or problematica) in the subdivisions of the Late Precambrian?

This was seen to depend on the previous question but opinions were: 'in our opinion such zones certainly exist'; '. . .I think it likely that a boundary will be agreed which will make some rocks with animal fossils Precambrian in age'. Some doubt was expressed regarding the value of trace fossils in zones. 'Progress achieved in study of Precambrian animal fossils enables us to understand that sooner or later zones will be recognized but at the present time it is apparently not possible, especially if one takes into account zones in the sense of a standard scale and not local fossiliferous level.' 'In Late Precambrian several zones can be recognized.' '. . . it is quite probable that the Profallotaspis zone is a suitable level for. . . the boundary.' 'On ne peut pas parler de verritables biozones dans le Précambrien Supérieur...probablement possible dans l'avenir.' 'Zonation of the Late Precambrian should be based on the fossil animals only.'

3.d. Do you think it is possible to establish the Precambrian/Cambrian Boundary with acritarchs? Acritarchs, other like forms and floral assemblages may not be used to define Phanerozoic stratigraphy, faunal assemblages have precedence. Is the Precambrian/Cambrian Boundary a special case where acritarchs should be used because of the involvement of Precambiran zonal fossil assemblages in the considerations?

A fair consensus may be represented by one reply by two members: 'Zonation by acritarchs is probably not appropriate for the resolution of this problem because they have not been tested sufficiently on a world-wide basis.' 'They should be given due consideration in correlation but neither more nor less than other fossil fauna and flora... they should not take precedence in defining the Precambrian/Cambrian Boundary.' 'Acritarchs, not being animal fossils, will contradict the basis for existing Phanerozoic scales, but for some regions they are best for correlations.' 'Acritarchs... give... correlation ... for a number of regions.' "Nous ne connaissons pas encore les possibilités stratigraphiques des Acritarchs.' 'I do not think it is possible to establish the Cambrian/ Precambrian Boundary with acritarchs.' 'One should not ignore the assemblages of stromatolites which are successfully used for correlation of the Upper Precambrian.'

\section{3.e. Regarding the Aldan River sections:}

(i) Do you see some possibility for error in the use of these sections for stratigraphic definition?

(ii) Can a section on the Aldan and a point in the rock succession be used as a regional stratotype for the Precambrian/Cambrian boundary?

(iii) Can the Aldan, if it is judged to be worthy of a regional stratotype definition, be proposed as a candidate for an International Stratotype Section under the proposed programme of the IUGS Precambrian/Cambrian Boundary Working group?

'In all the sections the Working group examined, an unconformity is present between the Yudoma Formation and the Pestrotsvet Formation. Even if the contact is conformable, it represents a drastic facies change and therefore would have uncertain chronostratigraphic value.' This view was shared by others. 'A degree of possible error will not be larger than one zone; this error will be beyond detection provided by biostratigraphic method.' 'If the boundary is chosen within the sequence of shelly fossils a section on the Aldan might be considered for either a regional or an international stratotype.' Another view was 'Yes, especially in Pestrotsvet Formation. The Lena sections, e.g. Isit or even Zhurinsky Mys, might also be used and are of course more accessible...it would be expedient to place the boundary within the Tommotian Stage or at its top: the latter level seems to present some problems...' 'There can only be one point in a stratotype 
for the Precambrian/Cambrian Boundary where it is defined.' 'The sections of the Cambrian along the Aldan River...cannot be considered as suitable...for the Lower Cambrian Boundary.' 'There is some possibility of error in the use of any section including the Aldan sections. The Aldan sections as well as sections in Morocco and Australia should be studied in detail.' 'The Aldan River sections are not up to the most important condition of determining the chronostratigraphic boundaries - the section must be monofacial.'

\section{Interim Report of members of the Precambrian/Cambrian Boundary Working Group, Commission on Stratigraphy, I.U.G.S. present in east Siberia, July 1973}

\section{4.a. Working Reference Points}

Further work is planned by the Group on stratigraphical principles and practice in proposing an international Precambrian/Cambrian Boundary stratotype section and point. We select a number of Working Reference Points in the Aldan/Lena area which could satisfy criteria for international correlation of a Precambrian/Cambrian stratotype boundary point. The informal establishment of these Working Reference Points can provide a focus for further work in the U.S.S.R. and other parts of the world which possess well-developed correlatable Precambrian/Cambrian sections. In the area examined they are:

4.a. (i) At the base of Bed 13 in the section at Ulakhan-Sulugur on the Aldan. This is the base of the Dokidocyathus regularis zone and lies above the Aldanocyathus sunnaginicusTiksitheca licis zone.

4.a. (ii) At the base of Bed 10 in the section at Isit on the Lena. This is the base of the Dokidocyathus regularis zone and lies above the Aldanocyathus sunnaginicus-Tiksitheca licis zone. This section on the Lena River may be more easily accessible than that at Ulakhan-Sulugur on the Aldan.

4.a. (iii) The boundary suggested in the Excursion Guide by Rozanov, Missarzhevsky and others: the base of the Aldanocyathus sunnaginicus-Tiksitheca licis zone, on the Aldan at Ulakhan-Sulugur, seems to be associated there with facies changes, unconformities of unknown time gap (possibly small) and is presumably fundamentally based on the first known occurrence of shelly fossils.

4.a. (iv) A point related to the 'first' occurrence of trilobites in the Lena sections, i.e. Profallotaspis at Isit, has been suggested but some Soviet trilobite specialist opinion is that this may be difficult to establish because of the lack of trilobites in certain critical sections. We propose, therefore, a Working Reference Point at a point in the rock succession near the top of Bed 17 at Isit which is close to the present bottom of the range of Fallotaspis, thus leaving the present range of the zone of Profallotaspis below it.

The usefulness of these Working Reference Points depends on the international correlation which can be achieved for the zones of the Tommotian and Atdabanian Stages.

After further research it may be that one of these Working Reference Points (or a new one in east Siberia) may be a candidate for the international Precambrian/Cambrian Boundary Stratotype Section and Point, in competition with points found elsewhere in the world.

\section{4.b. Accessibility and conservation}

Accessibility to these excellently exposed and fossiliferous Working Reference Points is good: transport to Yakutsk by air and by boat from Yakutsk to the Aldan or the Lena in the summer ice-free season is straightforward. Boats can be used as living quarters and beached near the sections. Late June and early July are warm or hot; working conditions on the riverside exposures are good. There is no danger of the Reference Points being adversely affected by constructional development in the forseeable future. 


\title{
4.c. The definition of stages
}

The definition of stages in the Precambrian and Cambrian of east Siberia was not considered by the Working Group. It is thought that it may later be useful for the group to recommend the adoption of a geographically named system in the present late Precambrian below the Cambrian System.

The above Interim Report (section 4 of this letter) signed by: J. W. Cowie (Chairman), A. Yu. Rozanov (Secretary), G. Choubert, B. Daily, W. B. Harland, R. Michniak, A. R. Palmer, A. W. A. Rushton: the members of the Precambrian/Cambrian Boundary Working Group present on the Aldan/Lena excursion, June/July 1973.

\section{Other symposium activities}

5.a. Talks (chaired by Cowie) in the late afternoon, evening and night were given by many of the foreign geologists on a great variety of topics from specialized palaeontological results to syntheses covering large parts of the world. Particular emphasis was on the Precambrian/Cambrian transition in the strata and fossils in Australia, western Canada, Poland, Morocco, Iran, the D.D.R., western U.S.A., Newfoundland and Wales.

5.b. Informal discussion groups were always active during most of the twenty-four hours and time was also set aside for them; this was one of the most valuable of the symposium activities.

5.c. Occasional relaxations were swimming in the rivers and campfire groups on the shore.

Acknowledgements and thanks. Gratitude is expressed to the organizing committee under the chairmanship of Academician V. V. Menner and to the following sponsoring Institutes' organizers:

Geological Institute, Academy of Science, U.S.S.R. (Moscow).

Institute of Geology, Yakutsk Affiliate of the Siberian Department, Academy of Science, U.S.S.R.

Institute of Geology and Geophysics of the Siberian Department, Academy of Science, U.S.S.R. (Novosibirsk).

Scientific workers concerned from the Siberian Research Institute of Geology, Geophysics and Minerals Deposits (Novosibirsk).

Special thanks is given to the organizers of the field excursions, to the Headquarters staff of the Yakutsk Affiliate of the Siberian Department of the Academy of Science, especially K. Mokhantsev (Director), V. Vozin and M. Gorovatsky (Deputy Directors) and to the excursion guides. Among the many who worked hard in many ways to achieve a successful expedition were the indefatigable interpreters under the leadership of Rebecca Sorkina.

\author{
J. W. COWIE \\ Department of Geology \\ University of Bristol, England \\ A. YU. ROZANOV \\ Geological Institute \\ Academy of Science, U.S.S.R.
}

This Symposium reinforced once again the tradition of unstinted and highly organized Soviet effort for international geological science and the heart-warming hospitality of the people of the U.S.S.R.

1 st November 1973

J. W. COWIE 


\section{APPENDIX}

List of participants in the Symposium:

A. U.S.S.R.

V. V. Menner, K. Mokshantsev, I. Zhuravleva, N. Chernysheva, V. Savitsky, L. Egorova, L. Repina, V. Khomentovsky, B. Keller, A. Tugarinov, A. Yu. Rozanov, R. Sorkina, M. Raaben, G. Barkhatov, K. Mikhalev, N. Meshkova, L. Voronova, K. Mens, E. Posti, G. Fradkin, A. Mambetov, M. Vinkman, A. Gintsinger, V. Missarzhevsky, V. Popov, L. Borovikov, K. Khaiznikova,'M. Gnilovskaya, N. Lazarenko, V. Beloborodova, N. Suvorova, V. Korshunov, R. Bognibova, N. Zadorozhnaya, V. Luchinina, G. Vorontsova, T. Dolnik, G. Beljaeva, E. Pirrus, G. Ergaliev, Yu. Shabanov, B. Shishkin, V. Kiryanov, V. Zayka-Novatsky, P. Kolosov, A. Valkov, A. Shcheglov, Yu. Karagodin, A. Ragozina, V. Moston, T. Koptzeva, T. Kudzjavtzeva, G. Lugovtseva, S. Aivasova, E. Minina.

\section{B. Foreign}

Australia: B. Daily. Britain: J. W. Cowie, T. P. Fletcher, W. B. Harland, S. C. Matthews, A. W. A. Rushton. Canada: J. W. Aitken, H. J. Hofmann. Denmark: V. Poulsen. D.D.R.: G. Burmann, A. Zollig. B.R.D.: K. Sdzuy. France: G. Choubert, F. Debrenne, M. Debrenne, A. Faure-Muret. Iran: J. Stöcklin. Poland: B. Aren, J. Kazmierczak, K. Lendzion, R. Michniak, S. Orlowski. Sweden: S. Bengtson. U.S.A.: R. A. Gangloff, C. A. Nelson, A. R. Palmer, J. Rodgers. 


\section{EXPLANATION OF PLATES}

Plate 1. The cliffs of the Aldan River bank at Ulakhan-Sulugur. The paler-hued strata near the water-line are part of the Yudoma Formation overlain by Pestrotsvet Formation while the upper parts of the cliff are formed in the Tumuldur Formation (see Fig. 2).

Plate 2. The cliffs of the Lena River bank at Isit. The trench was excavated specially for the Symposium visit to complete the exposed succession from the water-line upwards (see Fig. 4).

Plate 3. The cliffs of the Lena River bank at Zhurinsky Mys (see Fig. 7).

Plate 4. The cliffs of the Lena River bank at Labaia (the famous 'Pillars of the Lena') the succession is in the younger strata of the Lower Cambrian. 
Geol. Mag. Vol. 111, 1974, Cowie \& Rozanov, Plates 1-4, between pp. 252 and 253.

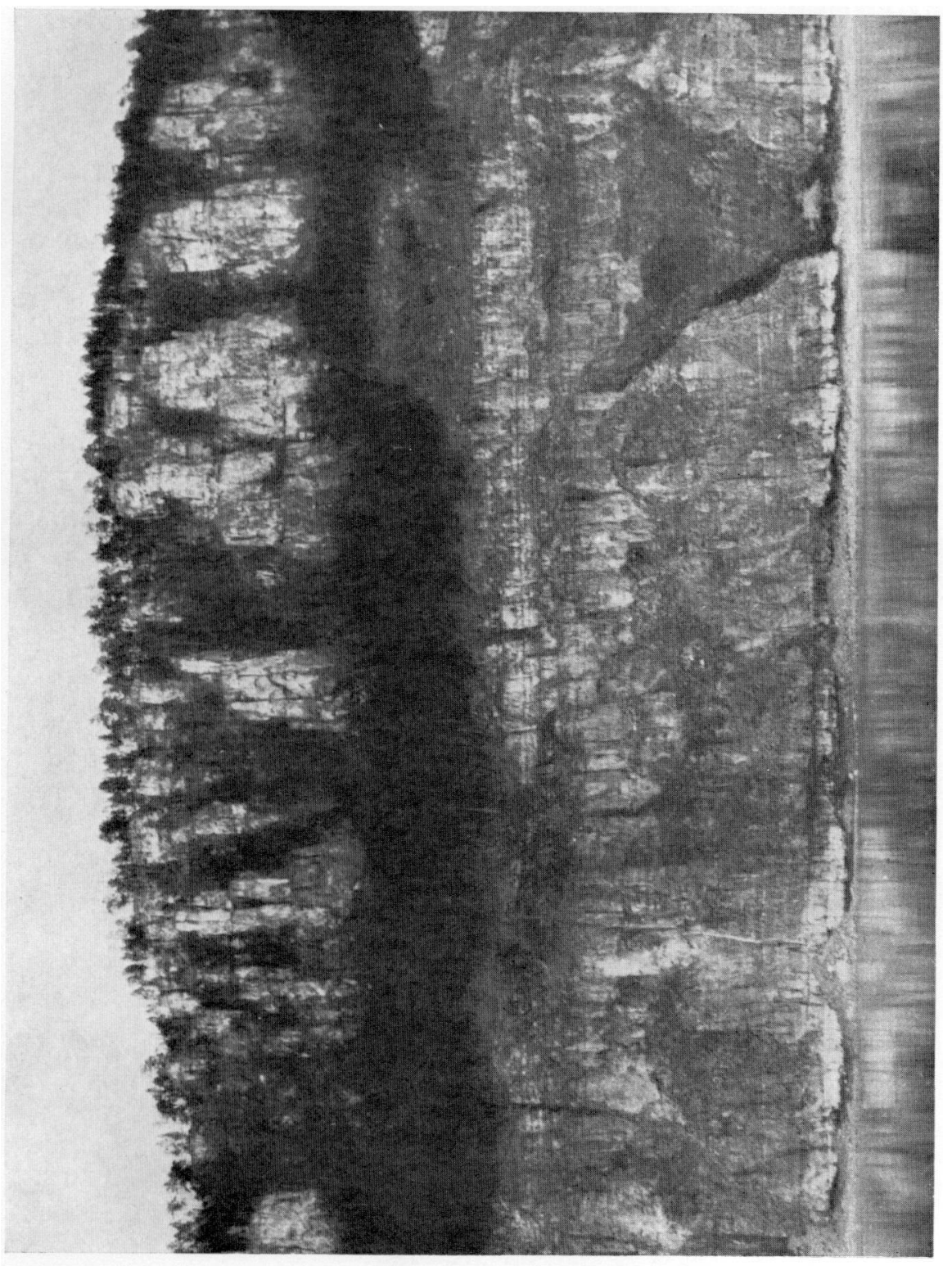

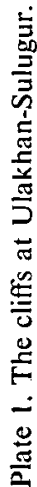


Geol. Mag. Vol. 111, 1974, Cowie \& Rozanov, Plate 2.

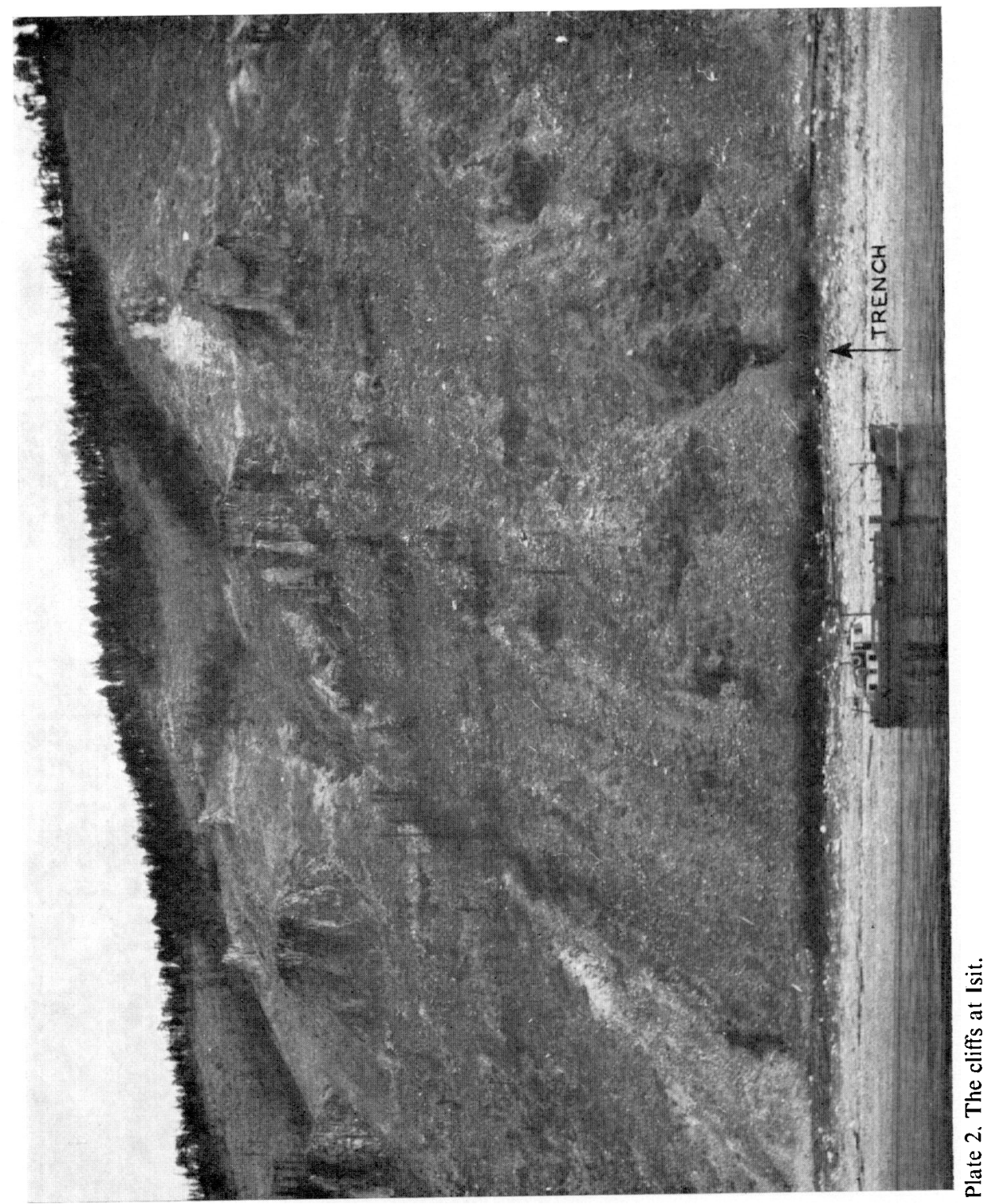


Geol. Mag. Vol. 111, 1974, Cowie \& Rozanov, Plate 3.

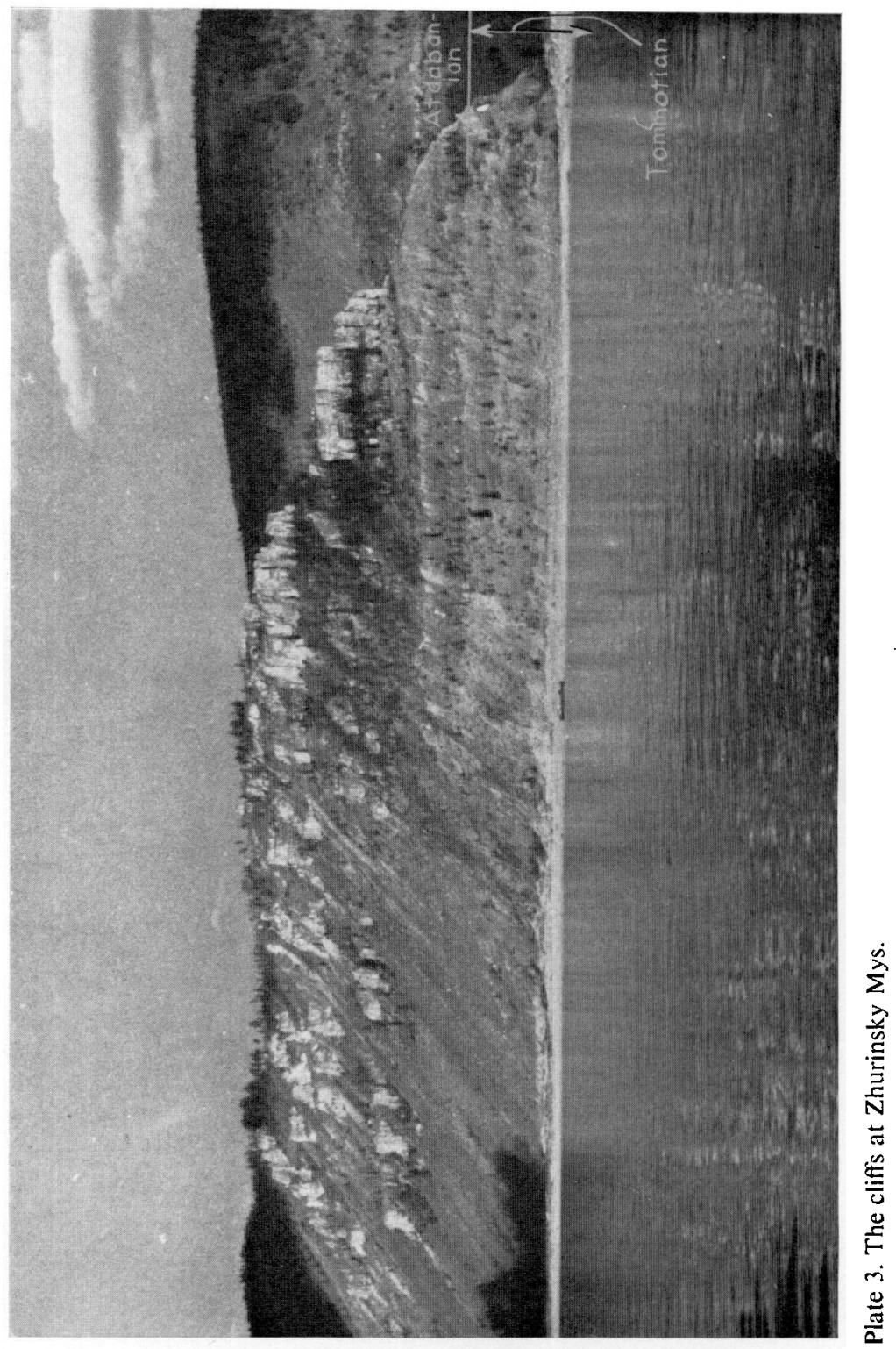


Geol. Mag. Vol. 111, 1974, Cowie \& Rozanov, Plate 4.

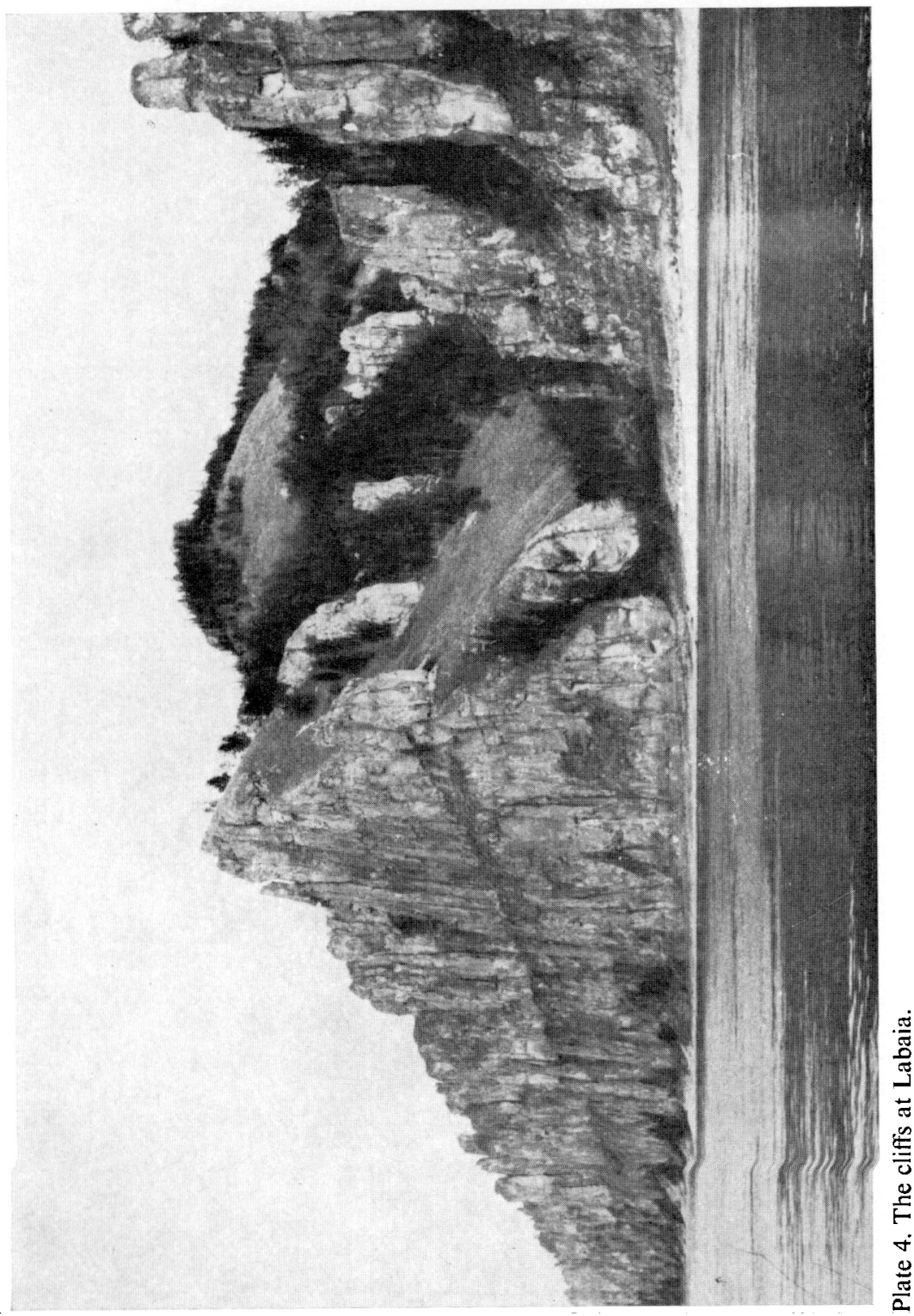

